\title{
Molecular cloning and characterization of an amidase from Arabidopsis thaliana capable of converting indole-3-acetamide into the plant growth hormone, indole-3-acetic acid
}

\author{
Stephan Pollmann, Daniel Neu, Elmar W. Weiler* \\ Lehrstuhl für Pflanzenphysiologie, Ruhr-Universität Bochum, D-44780 Bochum, Germany
}

\begin{abstract}
Acylamidohydrolases from higher plants have not been characterized or cloned so far. AtAMI 1 is the first member of this enzyme family from a higher plant and was identified in the genome of Arabidopsis thaliana based on sequence homology with the catalyticdomain sequence of bacterial acylamidohydrolases, particularly those that exhibit indole-3-acetamide amidohydrolase activity. AtAMI1 polypeptide and mRNA are present in leaf tissues, as shown by immunoblotting and RT-PCR, respectively. AtAMI1 was expressed from its cDNA in enzymatically active form and exhibits substrate specificity for indole-3-acetamide, but also some activity against L-asparagine. The recombinant enzyme was characterized further. The results show that higher plants have acylamidohydrolases with properties similar to the enzymes of certain plant-associated bacteria such as Agrobacterium-, Pseudomonasand Rhodococcus-species, in which these enzymes serve to synthesize the plant growth hormone, indole-3-acetic acid, utilized by the bacteria to colonize their host plants. As indole-3-acetamide is a native metabolite in Arabidopsis thatiana, it can no longer be ruled out that one pathway for the biosynthesis of indole-3-acetic acid involves indole-3-acetamide-hydrolysis by $A t$ AMI1.
\end{abstract}

Keywords: Arabidopsis thaliana; Brassicaceae; Crucifers; Indole-3-acetic acid; Indole-3-acetamide; Indole-3-acetonitrile; Nitrilases; Acylamide amidohydrolase; Amidase

\section{Introduction}

Indole-3-acetic acid (IAA) is the major plant growth hormone and is involved in the regulation of almost every step in plant development. The routes by which plants synthesize IAA are only incompletely understood at present, but several lines of evidence, including the impossibility to select IAA-deficient mutants, suggest that more than a single pathway is operative (Eckhardt, 2001). The lack of detailed knowledge about the enzymes involved in the biosynthesis of IAA and their inaccessibility to molecular and functional analysis are obstacles to a better understanding of the biology of the plant growth hormone IAA.

The only pathway to IAA that has been worked out completely is the prokaryotic route from L-tryptophan

* Corresponding author. Tel.: +49-234-3224291; fax: +49-2343214187.

E-mail address: elmar.weiler@ruhr-uni-bochum.de (E.W. Weiler). to IAA via indole-3-acetamide (IAM). This pathway is operative in several genera of plant-associated bacteria including Agrobacterium (Weiler and Schröder, 1987), Azospirillum (Bar and Okon, 1993), Pseudomonas (Magie et al., 1963) and Streptomyces (Manulis et al., 1994). The conversion is catalyzed by tryptophan-2monooxygenase (L-tryptophan $\rightarrow$ IAM) and indole-3acetamide hydrolase (IAM $\rightarrow$ IAA). It is generally held that this pathway is not operative in higher plants. Earlier reports on the occurrence of IAM in a few plants, namely rice (Kawaguchi et al., 1991), Poncirus trifoliata (Kawaguchi et al., 1993), Prunus jamasakura (Saotome et al., 1993) and Citrus unshiu (Igoshi et al., 1971; Takahashi et al., 1975) dealt with the analysis of plant material which was not raised under sterile conditions, thus leaving room for a microbial contribution of this metabolite. However, it was recently shown in our laboratory that IAM is a true endogenous metabolite of Arabidopsis thatiana and that the level of IAM in the plant varies with developmental stage (Pollmann et al., 
2002). Quantitative analysis in this study clearly revealed further metabolism of IAM during early seedling growth. However, no enzymatic activity able to metabolize IAM has so far been identified in a plant.

In this study, we show that the genome of Arabidopsis thaliana contains a small family of genes encoding amidase-like proteins ( $A M I 1$ to $A M I 4)$. One of these $(A M I 1)$ encodes an amidase with significant sequence similarity to the IAM-hydrolyzing bacterial amidases. Expression of AtAMI 1 cDNA in E. coli yielded a functional enzyme which showed substrate specificity for IAM. The AtAMI1 gene is expressed in leaves throughout the rosette stage. These data prove the existence of an hitherto unknown enzyme in plants able to convert IAM to the plant hormone IAA. This, together with the occurrence of IAM as an endogenous metabolite and a mechanism for its formation from indole-3-acetonitrile (Pollmann et al., 2002) suggests that one route of IAA-biosynthesis in $A$. thaliana operates via indole-3acetamide. We have found no evidence, based on sequence similarities with the prokaryotic enzymes, however, for the occurrence of tryptophan-2-monooxygenase-encoding gene(s) in the genome of $A$. thaliana. Convention: throughout this text, AtAMI designates the polypeptide, while AtAMI1 designates the gene, in accordance with established rules for Arabidopsis thaliana.

\section{Results}

\subsection{Molecular cloning of Arabidopsis amidase 1 cDNA and its functional expression in Escherichia coli}

The identification and metabolic conversion of IAM in A. thaliana (Pollmann et al., 2002) led us to consider the occurrence of an IAM-amidase in this species. To date, no enzyme with IAM-amidase property has been described in plants, and no acylamide amidohydrolase has been cloned from any plant. The bacterial IAM-amidohydrolases, on the other hand, share a highly conserved stretch of 118 amino acids including the catalytic site residues (Fig. 1). Using the amino acid sequence information of this region of the Agrobacterium tumefaciens and the Agrobacterium vitis IAM-amidohydrolases, a blastp database search of the Arabidopsis genome returned four hits representing four different, annotated genes encoding putative polypeptides with $39.1-60.4 \%$ sequence similarity (identical plus similar amino acids) in a region covering the search sequences.
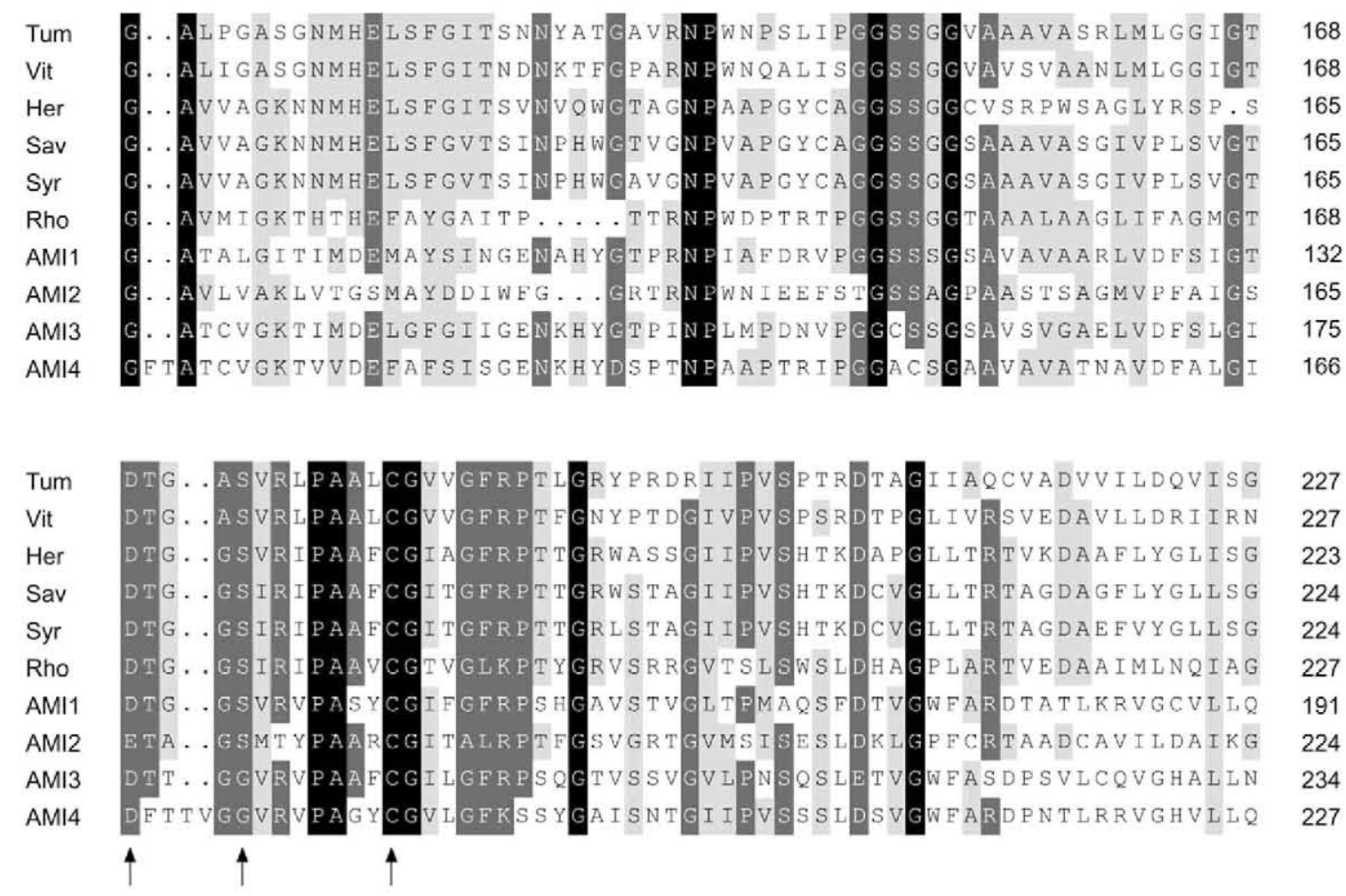

Fig. 1. Sequence alignments of six indole-3-acetamide hydrolases from plant pathogenic bacteria with the sequences of the four Arabidopsis thaliana amidases (AMI1-AMI4). The sequences are: Agrobacterium tumefaciens (Tum, P25016), Agrobacterium vitis (Vit, Q04557), Erwinia herbicola (Her, Q47860), Pseudomonas savastanoi (Sav, P06618), Pseudomonas syringae (Syr, P52831) and Rhodococcus sp. (Rho, M74531; Kobayashi et al., 1997). Amino acid positions are indicated. Identities and similarities among the different classes of proteins are indicated in black or grey boxes, respectively. The arrows denote residues presumably involved in catalysis. 
The genes were given the acronyms AtAMI1 to AtAMI4. In Fig. 1, the corresponding amino acid sequences of the encoded polypeptides, AtAMI 1 to AtAMI4, are compared with the prokaryotic sequences and particularly to that of Rhodococcus sp. amidohydrolase (EC 3.5.1.4, GenBank M74531), an enzyme known to hydrolyze IAM into IAA and ammonia (Klee et al., 1984; Yamada et al., 1985), but utilizing also, e.g., fatty acid amides (Cravatt et al., 1996) as substrates. The active site of this enzyme has been analyzed in most detail (Kobayashi et al., 1997) and was shown to include Asp-168 and Ser-173 rather than Cys-181, a residue hitherto assumed to be involved in catalysis (Fig. 1, arrows). As can be seen, only AtAMI1 contains both,

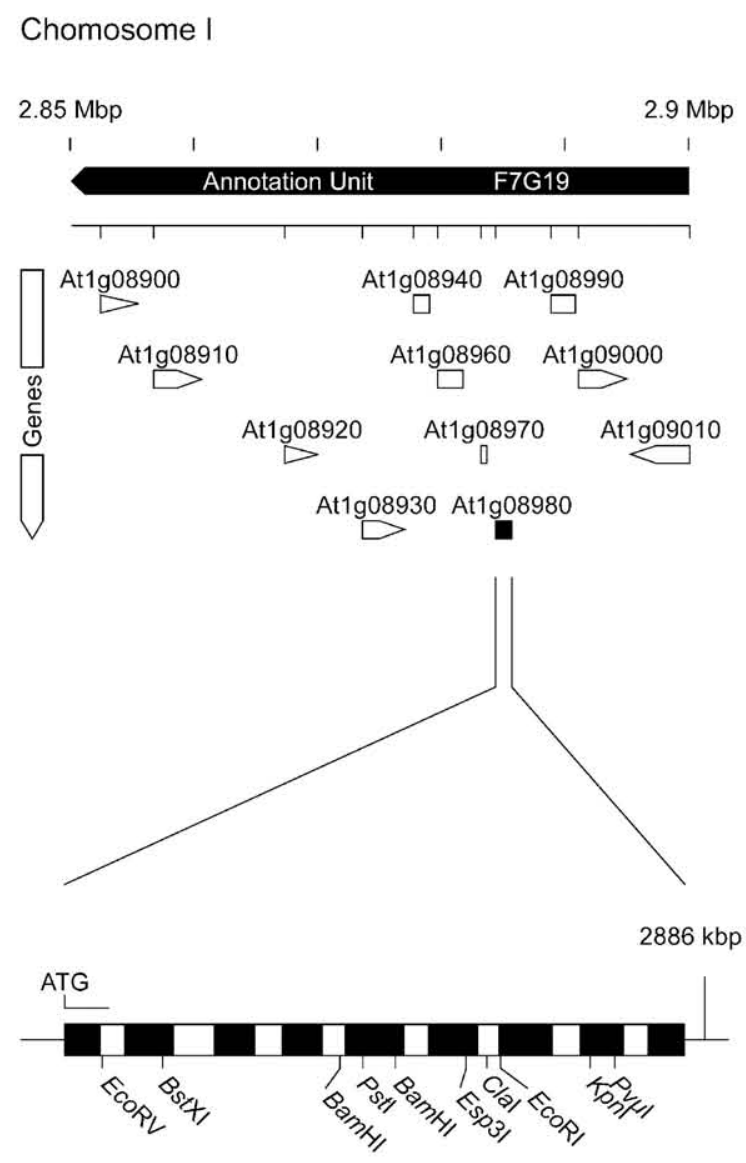

Fig. 2. Location and genomic organisation of the AtAMI1-gene (At1g08980) on Arabidopsis thaliana chromosome I. ATG indicates the $5^{\prime}$ - to $3^{\prime}$-direction of the gene. Introns are shown in white. The genes surrounding AtAMI1 (Atg08980, black bar) are: At1g08900, putative sugar transport protein, ERD6 (gb BAA25989); At1g08910, hypothetical protein (genefinder); Atlg08920, putative sugar transport protein, ERD6 (gb BAA25989); Atlg08930, zinc finger protein ATZF1, putative; At1g08940, similar to Saccharomyces hypothetical protein YDR051c (gb Z49209) [hypothetical ORF]; Atlg08950, tRNA Pro; Atlg08960, similar to Caenorhabditis hypothetical protein CO7A9 11 (gb Z29094) [Na/Ca, K antiporter]; Atlg08970, similar to Schizosaccharomyces CCAAT binding factor (gb U88525); Atlg08990, unknown protein; At1g09000, similar to Nicotiana protein kinase-2 (NPK-1 related); Atlg09010, similar to Bos $\beta$-mannosidase (gb U46067) [Capra hircus $\beta$-mannosidase]. the homologous Asp and the Ser, while the other three sequences lack either the catalytically important Asp- or the Ser-residue. Thus, AtAMI1 was characterized further in this study. The AtAMI1-gene (former designation Atlg08980) is located on the left arm of chromosome I in annotation group F7G19 and is at 2.884 Mbp distance from the telomere. The basic architecture of the AtAMI1-gene is shown in Fig. 2.

AtAMI1 was found to be transcribed in leaves throughout the rosette stage as shown by RT-PCR. Using the constitutively active AtNIT1 gene (Hillebrand et al., 1998) as an internal marker, it became evident that AtAMI1 was also constitutively active in leaf tissue (Fig. 3).

Cloning of the AtAMI1-cDNA into the plasmid pASK-IBA5 and expression of this cDNA in the XL-1 blue strain of $E$. coli (when in stationary phase) resulted in the anhydrotetracycline-inducible synthesis of small amounts of soluble amidase protein. As successful expression was not observed in other, more leaky, $E$. coli expression systems (e.g. pQE-30, Qiagen) and highlevel expression was also not observed, we assume that the presence of the AtAMI1-polypeptide in bacterial cells is toxic. However, the recombinant AtAMI1-protein could be purified to apparent homogeneity (SDSPAGE) utilizing its N-terminal Strep-tag peptide as described in the Experimental (Section 4) (Fig. 4).

\subsection{Characterization of recombinant, purified AtAMII}

Recombinant, Strep-tagged AtAMI1 had an apparent molecular mass of $45 \mathrm{kDa}$ on SDS-PA gels (calculated: $46.2 \mathrm{kDa}$ ). As bacterial acylamidohydrolases are usually active as dimers (e.g. Kobayashi et al., 1993), we estimated the subunit state of purified recombinant AtAMI1 on non-denaturing blue native electrophoresis gels (Fig. 5). Strep-tagged AtAMI1 exclusively occurred as a monomer.

The recombinant AtAMI1-polypeptide showed, in preliminary experiments, IAM-hydrolase activity. IAM was thus used as substrate in order to characterize general properties of the enzyme. The reaction rate was constant under standard conditions $\left(T=30^{\circ} \mathrm{C}, \mathrm{pH}=7.5\right.$, $5 \mu \mathrm{g}$ of recombinant enzyme, $10 \mathrm{mM}$ substrate) for at

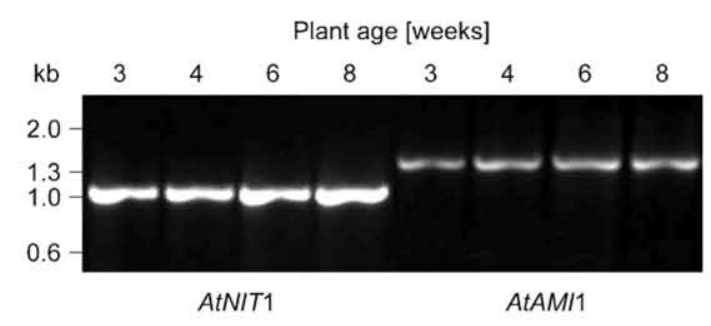

Fig. 3. RT-PCR on Arabidopsis leaf material. Gene-specific primers were used. The nitrilase-1-gene (AtNIT1), which is known to be expressed ubiquitously in leaves, was used as an internal control. 
least $4 \mathrm{~h}$, and the $\mathrm{pH}$-optimum (buffer: $100 \mathrm{mM}$ sodium phosphate) was at 7 . Enzyme activities sharply declined at $\mathrm{pH}>8$ and $\mathrm{pH}<6$. At $\mathrm{pH} 7$, the temperature optimum was found to be $35-37^{\circ} \mathrm{C}$. At $T>37^{\circ} \mathrm{C}$ activity drastically declined. The standard temperature chosen for the enzymatic assay was set at $30^{\circ} \mathrm{C}$. The linear range of the assay with respect to the amount of enzyme protein was from 0 to $5 \mu \mathrm{g}$ per reaction $(5 \mu \mathrm{g}$ set as the standard).

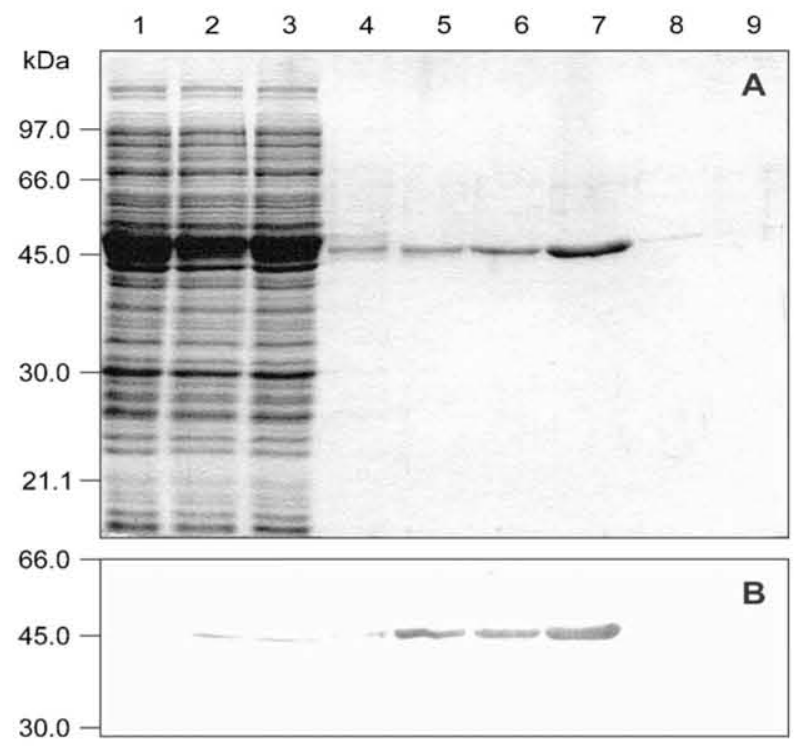

Fig. 4. Purification of heterologously expressed AtAMI1 fusion protein. Lane 1 crude extract, lane 2 column flow-through, lanes 3, 4 washing fractions $(4 \mathrm{ml})$, lanes 5 to 9 eluted fractions $(2 \mathrm{ml}) . A$, Coomassie brilliant blue stained $12.5 \%$ SDS-polyacrylamide gel containing $5 \mu \mathrm{l}$ of the sample in each lane. B, Detection of the blotted AtAMI1 fusion-protein with a StrepTactin-alkaline phosphatase conjugate.

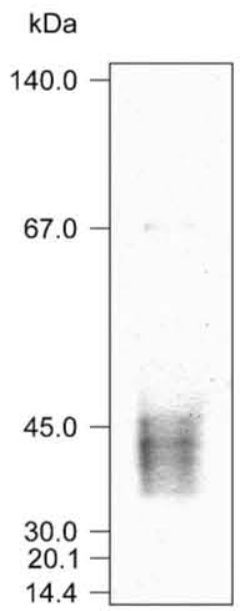

Fig. 5. Blue native PAGE separation of AtAMI1. Strep-tagged amidase 1 was expressed in E. coli and purified by affinity chromatography. One $\mu \mathrm{g}$ of purified protein was used for gel electrophoresis on an $8-18 \%$ linear-gradient blue native gel system. The gel was stained with Coomassie brilliant blue.
When a range of several potential substrates was assayed for conversion by AtAMI1, it became evident that the enzyme preferred IAM over all other substrates tested (Fig. 6). A significant activity was also found for L-asparagine and 1-naphthalene acetamide, the latter yielding the active-but non-natural-auxin 1-naphthylacetic acid (1-NAA). L-Glutamine was not nearly as good a substrate as L-asparagine. The contamination of the AtAMI1-preparation with bacterial asparaginase was excluded, because no activity was found when extracts from bacteria transformed with the empty plasmid pASK-IBA5 were affinity-purified and the purified fraction corresponding to the AtAMI1-preparation was used as the source of protein in enzyme assays.

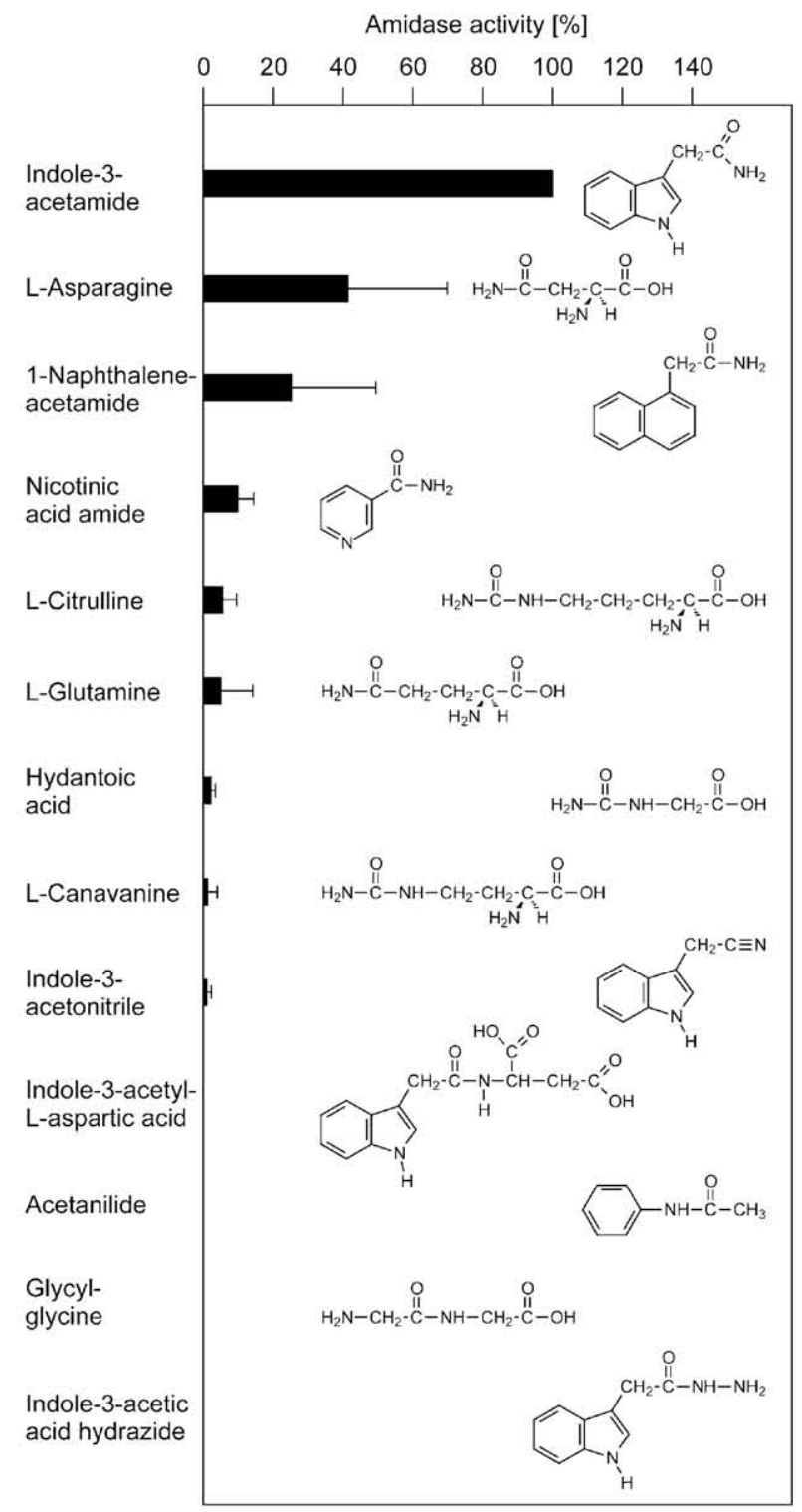

Fig. 6. Relative substrate conversion by AtAMI1. All assays were performed at $\mathrm{pH} 8.0$ and $30^{\circ} \mathrm{C}$ (substrate concentration $10 \mathrm{mM}$, reaction time $4 \mathrm{~h}$ ). The apparent specific activity of AtAMIl with 10 $\mathrm{mM}$ of IAM was 4.09 nkat (mg protein $)^{-1}$. The data shown are means \pm SD derived from $n \geqslant 4$ experiments. 
None of the other substrates was hydrolyzed, either, by this control protein fraction. For all activities given, blank reactions using boiled AtAMI1-protein were run in parallel and the values of the enzymatic conversions were corrected for any non-enzymatic hydrolysis in these boiled controls. The activities of AtAMI1 against IAM and L-Asn prompted us to test, as a substrate, IAA-L-aspartate, an amide conjugate of IAA and L-Asp which occurs widespread in plants including $A$. thaliana (Andersson and Sandberg, 1982; Östin et al., 1998). AtAMI1 did not detectably hydrolyze IAA-L-aspartate. Indole-3-acetonitrile was not a substrate, either, which is mechanistically interesting, as some acylamidohydrolases such as the Rhodococcus rhodochrous J1 amidase do hydrolyze nitriles to some extent (Kobayashi et al., 1998). AtAMI1 showed apparent Michaelis-Menten-kinetics for IAM-concentrations between 0 and 1 $\mathrm{mM}$, however, we were unable to show saturation even at substrate concentrations of $25 \mathrm{mM}$ which is near the solubility limit of the substrate, IAM. The linear double reciprocal plot (not shown) gave an apparent $K_{\mathrm{m}}$ for the substrate IAM of $972 \mu \mathrm{M}$.

In the final series of experiments, it was analyzed, if the occurrence of AtAMI1-mRNA (cf. Fig. 3) corresponded with the occurrence of the AMI1-polypeptide and the appropriate enzymatic activity in planta. AtAMI1-polypeptide was shown to occur in the soluble fraction of leaf proteins (apparent molecular mass 44 kDa, calculated: $44.8 \mathrm{kDa}$, Fig. 7). When this fraction of leaf proteins was enriched for AtAMI1 (see Experimental), the conversion of IAM to IAA could be shown unequivocally using deuterated precursor to avoid any confusion with endogenous material (spec. act. $2.22 \pm 0.71 \mathrm{pkat} / \mathrm{mg}$ protein; crude extract: $0.14 \pm 0.01$ $\mathrm{pkat} / \mathrm{mg}$ protein, $n=3$ ). After tryptic digestion or heat denaturation, the protein fractions were completely devoid of IAM-hydrolyzing activity. Thus, a non-enzy-

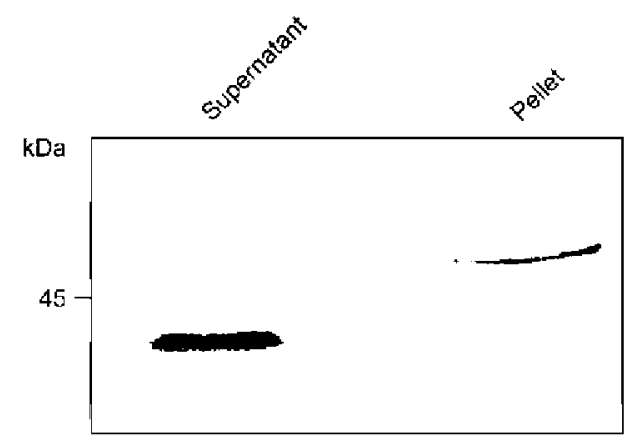

Fig. 7. Detection of AtAMI1 in an Arabidopsis thaliana protein extract. Proteins were extracted as described in the Experimental Procedures. Aliquots of $150 \mu \mathrm{g}$ of protein were used for exponential gradient SDS-gel electrophoresis and immunoblotting. The immunoblot only shows the region around $45 \mathrm{kDa}$. The endogenous AtAMI polypeptide was detected utilizing a polyclonal antibody (serum 645) raised against the affinity-purified, recombinant AtAMI1 polypeptide. matic reaction can be ruled out. Taken together, our data show that not only is the AtAMI1-gene transcribed, but the AtAMI1-protein and IAM-hydrolase activity are also present in the plant, both at very low levels.

\section{Discussion}

Indole-3-acetamide (IAM) is an endogenous metabolite in $A$. thaliana (Pollmann et al., 2002). One way of its formation is from indole-3-acetonitrile (IAN), a metabolite which is ubiquitous in $A$. thaliana, through the nitrile hydratase activity of the nitrilase isoforms 1 , 2, and 3 (Pollmann et al., 2002). The level of IAM in seeds is initially high, but the total amount of IAM per seedling decreases during germination and early seedling growth, clear evidence for further metabolism of the compound. We describe here a novel enzyme (and its gene) from $A$. thaliana which specifically hydrolyzes IAM to IAA and ammonia. This opens the possibility for a new biosynthetic route to the plant growth hormone, IAA, hitherto only known from a number of plant-associated bacteria. AtAMI1 belongs to a small gene family comprising four members, but is the only member within that family which encodes the complete set of amino acids required for catalysis in the group of bacterial IAM-amidohydrolases (Kobayashi et al., 1997) (cf. Fig. 1). As an extension of the data reported here, AtAMI2, when expressed from its cDNA in $E$. coli, is completely devoid of IAM-amidohydrolase activity (data not shown), although the catalytically relevant L-aspartate (Asp-133 in AtAMI1) is replaced by the functionally equivalent amino acid L-glutamate (Glu-166 in AtAMI2). The bacterial IAM-amidohydrolases act in concert with tryptophan-2-monooxygenases which synthesize IAM from L-Trp [see Weiler and Schröder (1987) for review]. The search for sequences homologous to one of the bacterial tryptophan-2-monooxygenases, however, has returned no hits, suggesting such enzymes do not occur in plants or are too divergent from their bacterial counterparts to be recognizable based on sequence inspection.

At present, it is unknown whether plant IAM-amidohydrolases occur widespread or are restricted to certain species, nor is the distribution of IAM in the plant kingdom known with certainty (see Introduction). However, in earlier work on the Agrobacterium tumefaciens iaaM gene, encoding tryptophan-2-monooxygenase, it was observed that expression of this gene in petunia and tobacco plants resulted in drastic symptoms of auxin overproduction and an increased level of IAM as well as of the auxin, IAA (Klee et al., 1987), suggesting that IAM to some extent was converted to IAA in these two species. It is, however, not excluded that chemical hydrolysis or a genuine auxin activity of 
IAM was responsible for the physiological responses observed in iaaM-transgenic plants.

Amide conjugates of IAA are an important component of auxin homeostasis in plants [see Bartel et al. (2001) for review]. The fact that both, IAM and L-Asn were hydrolyzed by AtAMI suggested, the enzyme could be involved in the hydrolysis of IAA-amino acid conjugates, particularly IAA- L-aspartate. However, this was clearly not the case (see Fig. 6). In agreement with this lack of activity is the fact that the amino acid sequence of AtAMI 1 is unrelated to the reported sequences of auxin amide-conjugate hydrolases from the bacterium Enterobacter agglomerans (Chou et al., 1998) and Arabidopsis thaliana (Davies et al., 1999; LeClere et al., 2002).

AtAMI1 represents a type of enzyme hitherto known only from a few plant-associated bacteria. One of these, Agrobacterium tumefaciens, introduces the iaaM-geneas part of the T-DNA- into the genome of higher plants (Weiler and Schröder, 1987). It will be interesting to analyze AtAMI1-homologs in other plant species and to study their evolutionary relationship. This may help to clarify the origin of this enzymatic activity which may have found its way from the biosynthetic repertoire of the higher plant into plant-associated bacteria or may have originated in prokaryotes and introgressed from there into the genomes of (some?) higher plants.

\section{Experimental}

\subsection{Plant material and growth conditions}

The experiments were carried out using Arabidopsis thaliana C24 (seed stock originally provided by L. Willmitzer, MPI-PP Golm, Germany). The plants were raised in a greenhouse on a 2:1 mixture of standard soil and sand for 4-5 weeks in short days (8-h photoperiod). Afterwards, plants were transferred to long days ( $16 \mathrm{~h}$ ). The greenhouse was maintained at $22-24{ }^{\circ} \mathrm{C}$ during the day and $18-20{ }^{\circ} \mathrm{C}$ during the night, with photosynthetically active radiation no less than $150 \mu \mathrm{mol}$ photons $\mathrm{m}^{-2} \mathrm{~s}^{-1}$ (supplementary light, if required, from sodium vapor lamps).

\subsection{Identification of the putative Arabidopsis amidase gene}

The 118-amino acids sequences of a highly conserved region of the indole-3-acetamide amidohydrolases of Agrobacterium tumefaciens (residues 109-227 from the N-terminus, HYIN_AGRT3, P25016) and Agrobacterium vitis (residues 109-227 from the N-terminus, HYIN_AGRVI, Q04557), were used as queries for TAIR BLAST database searches in blastp. Each of the two searches produced the same putative amidase genes.
The map position of the predicted AtAMI1-gene was located on the Arabidopsis Genomic Initiative (AGI) map using TAIR databases (http://www.arabidopsis.org). Further analysis of amino acid similarities were carried out using the DNAMAN 5.2.2 software (Lynnon BioSoft, Vaudreuil, Quebec, Canada).

\subsection{Vector construction, cloning and expression of AtAMII}

All basic molecular techniques were adapted from Sambrook et al. (1989) or Ausubel et al. (2000). Sequences obtained from reverse transcription-polymerase chain reaction (RT-PCR)-amplified cDNAs were verified by sequencing. As a general procedure, total RNA from leaves of non-sterile grown $A$. thaliana plants was prepared according to Barkan (1989). Reverse transcription was done by using the avian myeloblastosis virus RT-Kit (Promega) with oligo$\mathrm{d}(\mathrm{T})_{23}$ primers (Sigma) according to the manufacturers' instructions. The cDNAs were amplified by specific PCR using primers which allowed direct cloning into the Eco31I site of the pASK-IBA 5 vector (IBA GmbH, Göttingen, Germany). Primers were AMI1-IBA5-Strt (5'-TAT CGT GGT CTC GGC GCC GCG ACC AAT AAT GAT TTT GG-3'), AMI1-IBA5-Rev (5'-TAT CGT GGT CTC GTA TCA TCA AAT AAA TGC AGC AAG GG-3'). In addition, the NIT1 gene was coamplified as a control by using the following primer pair NIT1-Strt (5'-TAT ACT AGT ATG TCT AGT ACT AAA GAT- $\left.3^{\prime}\right)$ and NIT1-IBA3-Rev (5'-TTA TTA CGT CTC TGC GCT TTT GTT TGA GTC ATC CTC AG-3').

For overexpression, AtAMI1-cDNA (GenBank accession no. AF202077) was cloned into pASK-IBA 5 (IBA, Göttingen, Germany) resulting in a $\mathrm{N}$-terminal Strep-tag fusion of the encoded polypeptide. Protein expression was performed in Escherichia coli strain XL1 blue. Cells carrying the expression construct were 1:10 inoculated from fresh overnight bacteria suspensions and grown at $30^{\circ} \mathrm{C}$ to an optical density $(600 \mathrm{~nm})$ of 0.6. The expression of the recombinant proteins was then induced by adding $0.04 \mu \mathrm{g} / \mathrm{ml}$ anhydrotetracycline. After cultivation at $30^{\circ} \mathrm{C}$ for $4-5 \mathrm{~h}$ and harvest by centrifugation $\left(5000 \mathrm{~g}, 10 \mathrm{~min}, 4^{\circ} \mathrm{C}\right)$, the bacterial sediments were kept at $-80{ }^{\circ} \mathrm{C}$. All further steps were performed at $4{ }^{\circ} \mathrm{C}$ if not otherwise indicated. For extraction, the cells were resuspended in $1 / 10$ original volume of lysis buffer (100 mM K-Pi pH $8.0 ; 150 \mathrm{mM}$ $\mathrm{NaCl} ; 1 \mathrm{mM}$ EDTA), the lysis was carried out by six bursts of ultrasound (10 s, $40 \mathrm{~W})$ using an ultrasonic-tip (Sonifier B-17, Branson, Danbury, Conn., USA). The suspension was centrifuged $\left(10,000 \mathrm{~g}, 15 \mathrm{~min}, 4^{\circ} \mathrm{C}\right)$ and the clear supernatant, containing the soluble amidase, collected for subsequent expertiments.

The crude extract was ultrafiltrated (Centriprep ${ }^{\circledR}$ YM-10, Millipore) to an approximate volume of $10 \mathrm{ml}$. 
The affinity-tagged amidases were purified using a $1 \mathrm{ml}$ column of StrepTactin-sepharose (IBA, Göttingen, Germany). The bound proteins were eluted within the first $6 \mathrm{ml}$ of elution buffer $(100 \mathrm{mM} \mathrm{K}-\mathrm{Pi} \mathrm{pH} \mathrm{8.0,150}$ $\mathrm{mM} \mathrm{NaCl}, 1 \mathrm{mM}$ EDTA, $5 \mathrm{mM}$ D-desthiobiotin). The eluate was collected in $2 \mathrm{ml}$ fractions. The first three fractions were pooled and desalted using a PD-10 column (Amersham Pharmacia Biotech), equilibrated in 50 $\mathrm{mM}$ potassium phosphate ( $\mathrm{pH}$ 8.0). The purified amidase fraction showed a homogeneity of at least $95 \%$, as judged by Coomassie-blue staining of SDS-polyacrylamide gels.

\subsection{Preparation of plant protein and enrichment of amidase activity}

To prepare a plant protein extract, 6-8 week old plants were harvested and their leaf material was homogenized in $1 \mathrm{ml} / \mathrm{g}$ precooled extraction buffer (50 mM HEPES pH 7.5, $200 \mathrm{mM}$ sucrose, $3 \mathrm{mM}$ DTT, 3 mM EDTA). The extract was filtered through miracloth and centrifuged at $12,000 \times g$ for $45 \mathrm{~min}$. The resulting supernatant was brought to $70 \%$ saturation of $\left(\mathrm{NH}_{4}\right)_{2} \mathrm{SO}_{4}$ by adding a $100 \%$ satd. $\left(\mathrm{NH}_{4}\right)_{2} \mathrm{SO}_{4}$ solution dropwise. After stirring on ice for $1 \mathrm{~h}$, the precipitated proteins were collected by centrifugation $\left(12,000 \mathrm{~g}, 4{ }^{\circ} \mathrm{C}\right.$, $20 \mathrm{~min})$ and resuspended in a small volume $(5-10 \mathrm{ml}$, depending on the pellet size) of $50 \mathrm{mM} \mathrm{K-Pi,} \mathrm{pH} \mathrm{8.0.}$ Thereafter, the crude extract was dialysed against 500 volumes of $10 \mathrm{mM} \mathrm{K}-\mathrm{Pi}$, pH 8.0 at $4{ }^{\circ} \mathrm{C}$ overnight. Afterwards the extract was centrifuged at $100.000 \mathrm{~g}$ for $45 \mathrm{~min}$, separating the soluble proteins (supernatant) from the membrane fraction (pellet). The pellets were resuspended in $1 \mathrm{ml} 50 \mathrm{mM} \mathrm{K-Pi,pH} \mathrm{8.0.} \mathrm{After} \mathrm{deter-}$ mination of the protein concentration, $150 \mu \mathrm{g}$ of the protein fractions were precipitated with three volumes of $\mathrm{MeOH}$ and the proteins were separated by exponential gradient PAGE. To further enrich the amidase activity in the soluble protein fraction, the extract was chromatographically separated on a hydroxyapatite matrix, using a step gradient ( $5 \mathrm{mM} \mathrm{K}-\mathrm{Pi}, 50 \mathrm{mM} \mathrm{K}-\mathrm{Pi}$, $200 \mathrm{mM}$ K-Pi, $400 \mathrm{mM} \mathrm{K}-\mathrm{Pi}$, all pH 8.0). The AtAMI1 protein was eluted with the $50 \mathrm{mM}$ K-Pi buffer. The appropriate fractions were pooled and used for subsequent experiments.

\subsection{Antibody preparation and purification}

The protein was expressed and purified as described earlier. Four hundred microliters $(0.2 \mathrm{mg})$ of the purified Strep-AtAMI1 fusion protein were emulsified by sonication with an equal volume of Freund's incomplete adjuvant (Sigma) and subcutaneously injected into rabbits. The same amount of Strep-AtAMI1 protein was injected three more times in weekly intervals to preimmunize the animals. To boost the immune response, a $0.2 \mathrm{mg}$ protein sample was injected intramuscularly 6 weeks after the first injection. Blood was taken from the rabbits 1 and 2 weeks after each boost. The rabbit was boosted in a 1-month rhythm over a 6-month period. Blood was incubated at $4{ }^{\circ} \mathrm{C}$ overnight and the serum was harvested afterwards. To further purify the antibodies, a combination of ammonium sulphate and caprylic acid precipitation was utilized (McKinney and Parkinson, 1987).

\subsection{Enzymatic assay}

Amidase activity was determined by analyzing the ammonia produced during the reaction as previously described (Vorwerk et al., 2001). If not stated otherwise, the reaction was carried out in $1 \mathrm{ml} \mathrm{K}-\mathrm{Pi}$, pH 8.0, containing $5 \mu \mathrm{g}$ of the affinity purified protein. In case of expected product concentrations of less than $50 \mu \mathrm{M}$, for example when analyzing substrate concentration dependent activity, the amount of IAA produced was analyzed by HPLC (Pollmann et al., 2002). To determine the conversion of IAM in the enriched plant protein extract, $1 \mathrm{mg}$ of the protein fraction was incubated with $1 \mathrm{mM}\left[{ }^{2} \mathrm{H}\right]_{5}-\mathrm{IAM}$ in a total reaction volume of $500 \mu \mathrm{l}$ of $50 \mathrm{mM} \mathrm{K}-\mathrm{Pi}, \mathrm{pH} 8.0$, at $30^{\circ} \mathrm{C}$. As an internal standard, 75 pmol $\left[{ }^{2} \mathrm{H}\right]_{2}$-IAA was added and the amount of produced $\left[{ }^{2} \mathrm{H}\right]_{5}$-IAA was quantitated by GC/MS-MS (Pollmann et al., 2002). As a control, a tryptic digest of the same protein sample was used. In all cases, the reaction was stopped after $4 \mathrm{~h}$.

\subsection{General biochemical procedures}

Protein concentration was determined with Bradford's assay (Bradford, 1976) and bovine serum albumin as the standard. Amidase polypeptides were separated by 10 $20 \%(\mathrm{w} / \mathrm{v})$ gradients of polyacrylamide as described by Scharf and Nover (1982) or by SDS-PAGE (Laemmli, 1970). Proteins in gels were stained with Coomassie brilliant blue thereafter. For immunoblotting, the proteins were transferred to nitrocellulose (Towbin et al., 1979) after electrophoretical separation. For immunodetection, the anti-AMI1-antibody raised against the recombinant AtAMI1 protein was used at a final dilution of 1:1000. To detect the recombinant AMI1-fusion protein, a StrepTactin-alkaline phosphatase conjugate (IBA, Göttingen, Germany) was used. Non-denaturing, analytical blue native PAGE was carried out as described by Schägger et al. (1994).

\section{Acknowledgements}

This work was supported by the Deutsche Forschungsgemeinschaft, Bonn, Germany, and by Fonds der Chemischen Industrie, Frankfurt, Germany (literature provision). 


\section{References}

Andersson, B., Sandberg, G., 1982. Identification of endogenous $\mathrm{N}$-(3indoleacetyl)aspartic acid in scots pine (Pinus sylvestris L.) by combined gas chromatography-mass spectrometry, using high-performance liquid chromatography for quantification. J. Chromatogr. 238, 151-156.

Ausubel, F.A., Brent, R., Kingston, R.E., Moore, D.D., Seidman, J.G., Smith, J.A., Struhl, K., 2000. Current Protocols in Molecular Biology. John Wiley \& Sons, Inc, New York.

Bar, T., Okon, Y., 1993. Tryptophan conversion to indole-3-acetic acid via indole-3-acetamide in Azospirillum brasilense Sp 7. Can. J. Microbiol. 39, 81-86.

Barkan, A., 1989. Tissue-dependent plastid RNA splicing in maize: transcripts from four plastid genes are predominantly unspliced in leaf meristems and roots. Plant Cell 1, 437-445.

Bartel, B., LeClere, S., Magidin, M., Zolman, B.K., 2001. Inputs to the active indole-3-acetic acid pool: de novo synthesis, conjugate hydrolysis, and indole-3-butyric acid $\beta$-oxidation. J. Plant Growth Regul. 20, 198-216.

Bradford, M.M., 1976. A rapid and sensitive method for the quantitation of microgram quantities of protein utilizing the principle of protein-dye binding. Anal. Biochem. 72, 248-254.

Chou, J.-C., Mulbry, W.W., Cohen, J.D., 1998. The gene for indole-3acetyl-L-aspartic acid hydrolase from Enterobacter agglomerans: molecular cloning, nucleotide sequence, and expression in Escherichia coli. Mol. Gen. Genet. 259, 172-178.

Cravatt, B.F., Giang, D.K., Mayfield, S.P., Boger, D.L., Koner, R.A., Gilula, N.B., 1996. Molecular characterization of an enzyme that degrades neuromodulatory fatty-acid amides. Nature (London) 384, 83-87.

Davies, R.T., Goetz, D.H., Lasswell, J., Anderson, M.N., Bartel, B., 1999. IAR3 encodes an auxin conjugate hydrolase from Arabidopsis. Plant Cell 11, 365-376.

Eckhardt, N.A., 2001. New insights into auxin biosynthesis. Plant Cell 13, 1-3.

Hillebrand, H., Bartling, D., Weiler, E.W., 1998. Structural analysis of the $N I T 2 / N I T 1 / N I T 3$ gene cluster encoding nitrilases, enzymes catalyzing the terminal activation step in indole acetic acid biosynthesis in Arabidopsis thaliana. Plant Mol. Biol. 36, 89-99.

Igoshi, M., Yamaguchi, I., Takahashi, N., Hirose, K., 1971. Plant growth substances in the young fruit of Citrus unshiu. Agric. Biol. Chem. 35, 629-631.

Kawaguchi, M., Kobayashi, M., Sakurai, A., Syono, K., 1991. The presence of an enzyme that converts indole-3-acetamide into IAA in wild and cultivated rice. Plant Cell Physiol. 32, 143-149.

Kawaguchi, M., Fujioka, S., Sakurai, A., Yamaki, Y.T., Syono, K., 1993. Presence of a pathway for the biosynthesis of auxin via indole-3-acetamide in trifoliata orange. Plant Cell Physiol. 34, 121128.

Klee, H.J., Horsch, R.B., Hinchee, M.A., Hein, M.B., Hoffmann, N.L., 1987. The effects of overproduction of two Agrobacterium tumefaciens T-DNA auxin biosynthetic gene products in transgenic petunia plants. Genes \& Development 1, 86-96.

Klee, H., Montoya, A., Horodyski, F., Lichtenstein, C., Garfunkel, D., Fuller, S., Flores, C., Peschon, J., Nester, E., Gordon, M., 1984. Nucleotide sequence of the tms gene of the pTiA6NC octopine Ti plasmid: two gene products involved in plant tumorigenesis. Proc. Natl. Acad. Sci. USA 81, 1728-1732.

Kobayashi, M., Fujiwara, Y., Goda, M., Komeda, H., Shimizu, S., 1997. Identification of active sites in amidase: evolutionary rela- tionship between amide bond- and peptide-bond cleaving enzymes. Proc. Natl. Acad. Sci. USA 94, 11986-11991.

Kobayashi, M., Goda, M., Shimizu, S., 1998. The catalytic mechanism of amidase also involves nitrile hydrolysis. FEBS Lett. 439, 325-328.

Kobayashi, M., Komeda, H., Nagasawa, T., Nishiyama, M., Horinouchi, S., Beppu, T., Yamada, H., Shimizu, S., 1993. Amidase coupled with low-molecular-mass nitrile hydratase from Rhodococcus rhodochrous J1- Sequencing and expression of the gene and purification and characterization of the gene product. Eur. J. Biochem. 217, 327-336.

Laemmli, U.K., 1970. Cleavage of structural proteins during the assembly of the head of bacteriophage T4. Nature 227, 680-685.

LeClere, S., Tellez, R., Rampey, R.A., Matsuda, S.P.T., Bartel, B., 2002. Characterization of a family of IAA-amino acid conjugate hydrolases from Arabidopsis. J. Biol. Chem. 277, 20446-20452.

Magie, A.R., Wilson, E.E., Kosuge, T., 1963. Indoleacetamide as an intermediate in the synthesis of indole acetic acid in Pseudomonas savastanoi. Science 141, 1281-1282.

Manulis, S., Shafir, H., Epstein, E., Lichter, A., Barash, I., 1994. Biosynthesis of indole-3-acetic acid via the indole-3-acetamide pathway in Streptomyces spp. Microbiology 140, 1045-1050.

McKinney, M.M., Parkinson, A., 1987. A simple, non-chromatographic procedure to purify immunoglobulins from serum and ascites fluid. J. Immunol. Meth. 96, 271-278.

Östin, A., Kowalyczk, M., Bhalerao, R.P., Sandberg, G., 1998. Metabolism of indole-3-acetic acid in Arabidopsis. Plant Physiol. 118, 285-296.

Pollmann, S., Müller, A., Piotrowski, M., Weiler, E.W., 2002. Occurrence and formation of indole-3-acetamide in Arabidopsis thaliana. Planta 216, 155-161.

Sambrook, J., Fritsch, E.F., Maniatis, T., 1989. Molecular Cloning: A Laboratory Manual. Cold Spring Harbor Laboratory Press, Cold Spring Harbor, New York.

Saotome, M., Shirahata, K., Nishimura, R., Yakaba, M., Kawaguchi, M., Syono, K., Kitsuwa, T., Ishii, Y., Nakamura, T., 1993. The identification of indole-3-acetic acid and indole-3-acetamide in the hypocotyls of Japanese cherry. Plant Cell Physiol. 34, 157-159.

Schägger, H., Cramer, W.A., von Jagow, G., 1994. Analysis of molecular masses and oligomeric state of protein complexes by blue native electrophoresis and isolation of membrane protein complexes by twodimensional native electrophoresis. Anal. Biochem. 217, 220-223.

Scharf, K.-D., Nover, L., 1982. Heat-shock-induced alterations of ribosomal protein phosphorylation in plant cell cultures. Cell Sep. $30,427-437$.

Takahashi, N., Yamaguchi, I., Kono, T., Igoshi, M., Hirose, K., Suzuki, K., 1975. Characterization of plant growth substances in Citrus unshitu and their change in fruit development. Plant Cell Physiol. 16, 1101-1111.

Towbin, H., Staehelin, T., Gordon, J., 1979. Electrophoretic transfer od proteins from polyacrylamide gels to nitrocellulose sheets: procedure and some applications. Proc. Natl. Acad. Sci. USA 76, 4350-4354.

Vorwerk, S., Biernacki, S., Hillebrand, H., Janzik, I., Müller, A., Weiler, E.W., Piotrowski, M., 2001. Enzymatic characterization of the recombinant Arabidopsis thaliana nitrilase subfamily encoded by the $N I T 2 / N I T 1 / N I T 3$-gene cluster. Planta 212, 508-516.

Weiler, E.W., Schröder, J., 1987. Hormone genes and the crown gall disease. TIBS 12, 271-275.

Yamada, T., Palm, C.J., Brooks, B., Kosuge, T., 1985. Nucleotide sequences of the Pseudomonas savastanoi indoleacetic acid genes show homology with Agrobacterium tumefaciens T-DNA. Proc Natl. Acad. Sci. USA 82, 6522-6526. 